\title{
Az egynapos sebészeti ellátás igénybevételi mutatóinak elemzése Magyarországon
}

\author{
Pónusz Róbert ${ }^{1}$ - Endrei Dóra dr. ${ }^{1,2}$ - Kovács Dalma ${ }^{1}$ \\ Németh Noémi $^{1}$ - Schiszler Bence ${ }^{3}$ - Molics Bálint dr. ${ }^{4}$ \\ Raposa László Bence dr. ${ }^{5}$ - Gulácsi László dr. ${ }^{6}$ \\ Gamal Eldin Mohamed dr. ${ }^{7}$ - Boncz Imre dr. ${ }^{1,2}$
}

\author{
${ }^{1}$ Pécsi Tudományegyetem, Egészségtudományi Kar, Egészségbiztosítási Intézet, Pécs \\ ${ }^{2}$ Pécsi Tudományegyetem, Klinikai Központ, Pécs \\ ${ }^{3}$ Pécsi Tudományegyetem, Egészségtudományi Kar, Sürgősségi Ellátási és Egészségpedagógiai Intézet, Pécs \\ ${ }^{4}$ Pécsi Tudományegyetem, Egészségtudományi Kar, Fizioterápiás és Sporttudományi Intézet, Pécs \\ ${ }^{5}$ Pécsi Tudományegyetem, Egészségtudományi Kar, Ápolástudományi Intézet, \\ Alapozó Egészségtudományi és Védőnői Intézet, Pécs \\ ${ }^{6}$ Budapesti Corvinus Egyetem, Gazdaságpolitika és Közpolitika Intézet, \\ Egészségügyi Közgazdaságtan Tanszék, Budapest \\ ${ }^{7}$ Budaörsi Egészségügyi Központ, Budaörs
}

Bevezetés: Az elmúlt évtizedek egyik legdinamikusabban fejlődő egészségügyi ellátási típusa az egynapos sebészet, amely számos ellátórendszeri, illetve szakmapolitikai előnyt prognosztizálhat.

Célkitüzés: Vizsgálatunk célja, hogy Magyarországon a 2010 és 2015 közötti időszak során közfinanszírozott formában elszámolt egynapos sebészeti esetszámokat és beavatkozásokat különböző aspektusokban elemezze.

Módszer: Retrospektív, kvantitatív típusú kutatásunk a Nemzeti Egészségbiztosítási Alapkezelő által biztosított adatbázison alapult, amely a 2010 és 2015 között közfinanszírozott formában elszámolt és az elszámolható egynapos sebészeti esetszámokat, a betegek nemét és életkorát, megye szerinti lakhelyét, az ellátóintézmények típusát, az ellátószakmák megnevezését, valamint a beavatkozások kódjait (OENO) tartalmazta.

Eredmények: A vizsgált, 2010 és 2015 közötti időszak során jelentősen emelkedett az egynapos formában ellátott esetek éves száma Magyarországon - 130 995-ról (2010) 251 328-ra (2015). Az egynapos ellátást igénybe vevő betegek átlagéletkora is jelentősen emelkedett, a 2010. évi 47,4 évról 2015-re 54,5 évre nőtt. 2010-ben az elszámolható egynapos sebészeti esetek mindössze $42 \%$-át számolták el ténylegesen a szolgáltatók egynapos sebészeti ellátásban, 2015-ben ez az arány már elérte a 65\%-ot. Hazánkban a szülészet-nőgyógyászati, a szemészeti, a sebészeti és az urológiai szakma jár élen az egynapos sebészeti ellátásban.

Következtetés: A vizsgált mutatók ismeretében az egynapos sebészet kiemelkedő fejlődését tapasztalhatjuk Magyarországon, különösen a szülészet-nőgyógyászati és a szemészeti szakma esetében.

Orv Hetil. 2019; 160(17): 670-678.

Kulcsszavak: egynapos sebészet, egészség-gazdaságtan, esetszám, Magyarország

\section{Analysis of the utilization of one-day surgery in Hungary}

Introduction: The impact of one-day surgery has been increasing since the past few decades. This type of health service could fulfil many requirements of health policy, health care services, governments as well as patients.

Aim: The aim of the research was to assess the publicly financed case numbers and interventions of one-day surgery in Hungary between 2010 and 2015 from different aspects.

Method: A retrospective and quantitative research was made, based on data of the National Health Insurance Fund of Hungary. The database contained all publicly financed one-day surgery cases (both theoretical and performed cases), 
intervention codes (WHO) as well as the related medical field. Then the database also contained all relevant information related to the patients (age, sex, residency according to the county) and the type of the provider health care institutions.

Results: Our results showed an increasing tendency according to the case numbers of one-day surgery from 130995 (2010) to 251328 (2015). The mean age of patients also increased in the analyzed period; in 2010: 47.4 years, in 2015: 54.5 years. In $2010,42 \%$ of the theoretically defined one-day surgery cases were practically performed as oneday surgery cases which increased significantly to $65 \%$ in 2015. Gynecology, ophthalmology, general surgery and urology have had a significant impact in one-day surgery in Hungary.

Conclusion: The analyzed data showed a significant increase of accounted cases, and we could identify the remarkable impact of gynecology and ophthalmology in one-day surgery in Hungary.

Keywords: one-day surgery, health economics, case numbers, Hungary

Pónusz R, Endrei D, Kovács D, Németh N, Schiszler B, Molics B, Raposa LB, Gulácsi L, Gamal Eldin M, Boncz I. [Analysis of the utilization of one-day surgery in Hungary]. Orv Hetil. 2019; 160(17): 670-678.

(Beérkezett: 2018. október 29.; elfogadva: 2018. december 4.)

\section{Rövidítések}

$\mathrm{ESWL}=($ extracorporeal shock wave lithotripsy $)$ a vese és a vesevezeték köveinek kezelése testen kívül gerjesztett lökéshullámmal; ESzCsM = Egészségügyi, Szociális és Családügyi Minisztérium; EüM = Egészségügyi Minisztérium; NEAK = Nemzeti Egészségbiztosítási Alapkezelő; $\mathrm{NM}=$ Népjóléti Minisztérium; OECD $=($ Organisation for Economic Co-operation and Development) Gazdasági Együttmúködési és Fejlesztési Szervezet; OENO = Orvosi Eljárások Nemzetközi Osztályozása; OEP = Országos Egészségbiztosítási Pénztár

Az egynapos sebészeti ellátás az elmúlt évtizedben számottevő és népszerú ellátási formaként jelent meg a fejlett egészségügyi ellátórendszerrel rendelkező országokban $[1,2]$. A fekvőbeteg-szakellátás vonatkozásában - annak magas költségigényességéből adódóan - már korábban megfogalmazásra került az egészségügyi kiadások mérséklését célzó eljárások bevezetésének támogatása [3]. Ezzel párhuzamosan napjainkban már kifejezett a betegek oldaláról is az igény az egészségügyi intézményben történő rövidebb tartózkodásra is $[4,5]$. A mútéti technikák folyamatos és jelentős volumenú fejlődésének köszönhetôen már több száz, korábban kizárólag osztályos bennfekvést indokló beavatkozás látható el az egynapos sebészeti ellátás keretein belül [6-10]. Az egynapos sebészeti beavatkozásokat követően a betegek rehabilitációja gyorsabban megvalósulhat, mint az aktív fekvő́beteg-szakellátásban, így a hamarabb visszanyert munkaképesség akár nemzetgazdasági jelentőséget is tulajdoníthat az ellátási típus szélesebb körben való alkalmazásának.

A nemzetközi szakirodalomban is megtalálhatók olyan közlemények, amelyek az egynapos sebészeti ellátás vonatkozásában pozitív eredményekrôl számolnak be az ellátási költségek csökkentése (kifejezetten az élelmezés, a mosodai és hotelszolgáltatás, a textíliafelhasználás terén) $[11,12]$, a magas betegbiztonság [13-15], a nosocomialis fertőzések kialakulásának megelőzése [14-17], valamint az ellátást követően megfogalmazott betegelégedettség [18-20] tekintetében.

Egynapos sebészeti ellátásról akkor beszélhetünk Magyarországon, amikor a betegek egészségügyi intézményben történő tartózkodása nem haladja meg a 24 órát. Az egynapos sebészeti ellátás a nemzetközi gyakorlatban döntően nappali ellátás keretein belül történik, a 24 órás ellátás jellemzően új mûtéti eljárások bevezetésekor vagy a posztoperatív szövődmények kockázata esetén jelenthet megoldást. Az Egészségügyi, Szociális és Családügyi Minisztérium 16/2002. számú, az egynapos sebészet szakmai feltételeiről szóló rendelete a következőképpen definiálja az egynapos sebészeti ellátást: „A beteg vagy a beteg törvényes képviselöjének beleegyezésével végzett olyan tervezhetó, tervezett (elektiv), az egészségügyi szakellátás társadalombiztositási finanszirozásának egyes kérdéseirōl szóló 9/1993. (IV. 2.) NM rendeletben kibirdetett beavathozás, amely az orvos szakképesitése, jártassága, a kötelezöen eloirt és szükséges infrastruktura, a beteg ambuláns mütéti kiválasztása és kivizsgálása szempontjainak függvényében az e célra kialakitott egyéb feltételrendszerekkel müködö intézményben történik. A beavatkozás után a beteg néhány órás szakfelïgyeletet igényel, amelyet egy ezen célra kialakitott fektetöben tölt. A szükséges megfigyelést követöen a beteg otthonába bocsátható. A beteg adott intézményben tartózkodása nem baladja meg a 24 órát” [21].

Vizsgálatunk célja, hogy elemezze Magyarországon a 2010 és 2015 közötti idôszakban közfinanszírozott formában elszámolt egynapos sebészeti esetszámokat a betegek, a betegek ellátását végző intézménytípusok, az érintett szakmák, valamint az elvégzett beavatkozások szerint.

\section{Adatok és módszer}

Vizsgálati adatbázisunk a Nemzeti Egészségbiztosítási Alapkezelő (a továbbiakban: NEAK) finanszírozási állományaiból származik. A vizsgált időszakban az egészség- 
biztosító szervezet az Országos Egészségbiztosítási Pénztár (a továbbiakban: OEP) volt. Az adatbázis a 2010 és 2015 közötti közfinanszírozott formában elszámolt egynapos sebészeti, illetve a 9/1993. (IV. 2.) NM rendelet 9. számú mellékletében rögzített beavatkozások alapján elszámolható esetszámokat tartalmazta. Az adatbázis ezen túl az egynapos sebészeti ellátás keretein belül ellátott betegek nemét, életkorát, megye szerinti állandó lakhelyét, az ellátóintézmény településének nevét, az ellátóintézet típusát, az ellátószakmák megnevezését, valamint a vizsgált időszak során ellátott és a NEAK által elszámolt, illetve elszámolható egynapos sebészeti esetszámokat foglalta magában.

A vizsgált beteganyag esetszámainak nemenkénti és korcsoportonkénti elemzése személteti az egynapos sebészeti ellátást igénybe vevő betegkör változását.

A kutatás során meghatároztuk az elszámolható és az elszámolt egynapos sebészeti esetszámok arányát a vizsgálati időszak valamennyi évében országosan, illetve intézménytípusonként. Elszámolható esetként definiáltuk a 9/1993. (IV. 2.) NM rendelet 9. számú mellékletében rögzített beavatkozásokkal elvégzett eseteket. Elszámolt esetként definiáltuk a NEAK által egynapos ellátásként finanszírozott esetszámokat. Az elszámolható és elszámolt esetszámok közötti eltérés lehetséges okait (például 24 óránál további hospitalizáció, nem egynapos kódolással indított elszámolás stb.) nem vizsgáltuk.

$\mathrm{Az}$ elszámolt egynapos sebészeti esetszámok arányát az elszámolható esetszámokhoz képest intézménytípusonként is megvizsgáltuk. Az intézménycsoportos bontás során a NEAK finanszírozási szerződéseiben használt nómenklatúrát, illetve csoportosítást alkalmaztuk (városi kórház, megyei kórház, fôvárosi kórház, gyermekkórház, egyetemi klinikák, országos intézetek).

Ezt követően az egynapos ellátások igénybevételének területi egyenlőtlenségeit elemeztük. Ehhez a tízezer lakosra vetített egynapos sebészeti esetszámot határoztuk meg megyei bontásban. A tízezer lakosra vetített adatok közlésénél az egyes megyék népességszámára vonatkozó adatok a Központi Statisztikai Hivatal (a továbbiakban: $\mathrm{KSH}$ ) interneten elérhető adataiból származnak [22].

Végezetül megvizsgáltuk, hogy mely szakmák végeznek legnagyobb számban egynapos ellátásokat, illetve azt, hogy - szakmáktól függetlenül - melyek a leggyakoribb egynapos sebészeti beavatkozások Magyarországon.

Az egyes orvosi szakmákat az egészségügyi szolgáltatók és múködési engedélyük nyilvántartásáról, valamint az egészségügyi szakmai jegyzékről szóló 2/2004. (XI. 17.) EüM rendelet 2. számú melléklete (a múködési engedélyek kiadásának alapjául szolgáló egészségügyi szakmák és kódjaik jegyzéke) alapján azonosítottuk.

A magyar egészségügyi rendszer felépítésének, múködésének [23-27] és erőforrás-gazdálkodásának kérdéseit a szakirodalom részletesen tárgyalja [28-32].
Adatainkat a Microsoft Excel 2016. évi verziójával (Microsoft Corporation, Redmond, WA, Amerikai Egyesült Államok) elemeztük, és leíró statisztikai próbákat végeztünk.

\section{Eredmények}

\section{Az egynapos sebészeti esetszámok emelkedése országosan és nemenként}

A 2010 és 2015 közötti időszakban vizsgált egynapos sebészeti esetszámok mértéke meghaladta az 1,2 milliót (1 215496 eset). Az országosan elszámolt egynapos sebészeti esetszámok a 2010. évben voltak a legalacsonyabbak (130 995 esetszám), 2015-ben pedig a legmagasabbak (251 328 esetszám). A 2011. évben elszámolt esetszámok mértéke 39\%-kal haladta meg a 2010. évben elszámolt mennyiséget. A 2012. évtől tovább emelkedtek az elszámolt esetszámok, ugyanakkor a növekedés már kevésbé volt jelentős mértékü. A vizsgálati időszak első és utolsó évében elszámolt esetszámokat egymáshoz viszonyítva, közel 192\%-os esetszám-növekedés állapítható meg (191,86\%). A vizsgálati időszakban az egynapos sebészeti ellátásban elszámolt esetszámok több mint 70\%-a nőbetegre vonatkozott (851 107 esetszám). Az ország demográfiai összetétele ugyanakkor nem magyarázza az egynapos sebészet fokozott női igénybevételét, ugyanis a vizsgálati időszak során a populációban a nők

1. táblázat A vizsgált egynapos ellátási beteganyag esetszámai nemenként, éves bontásban (2010-2015)

\begin{tabular}{lccc}
\hline Év & \multicolumn{3}{c}{ Esetszám } \\
\cline { 2 - 4 } & Férfi & Nő & Összesen \\
\hline 2010 & 32286 & 98709 & 130995 \\
2011 & 52138 & 129853 & 181991 \\
2012 & 61942 & 145482 & 207424 \\
2013 & 66665 & 150498 & 217163 \\
2014 & 70356 & 156239 & 226595 \\
2015 & 81002 & 170326 & 251328 \\
\hline Összesen & 364389 & 851107 & 1215496 \\
\hline
\end{tabular}

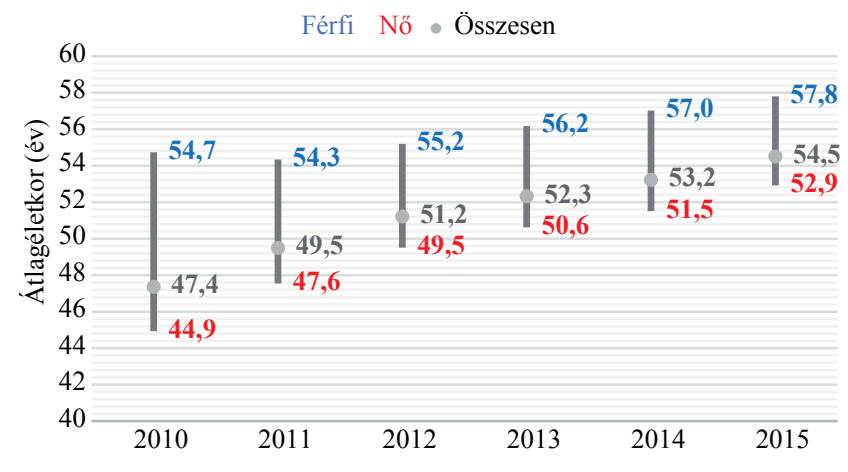

1. ábra $\mid$ Az egynapos sebészeti esetszámok átlagéletkora nemenkénti bontásban (2010-2015) 
aránya kismértékben haladta meg az 50\%-ot (52\%). Eredményeink szerint mind a női, mind pedig a férfiesetszámok vonatkozásában kifejezett esetszám-növekedés azonosítható a vizsgálati időszak első és utolsó évét illetően $(191,86 \%)$. A nők esetében több mint 70\%-kal emelkedett a 2015. évi esetszám a 2010. évihez képest (172,55\%); a férfiak vonatkozásában ez az arány még kifejezettebb, meghaladja a $250 \%$-ot $(250,89 \%)$ (1. táblá$z a t)$.

Az egynapos sebészet legfóképpen az aktív korú népesség körében rendelkezik számottevő jelentőséggel, ugyanis az ellátottak átlagéletkora nem érte el az 52 évet (51.79 év. CI $\lceil 95 \%\rceil=46.26-56.44)$. A 2015-ben egv- napos sebészeti keretek között ellátott betegek átlagéletkora (54,50 év) több mint 7 évvel nőtt $(7,14$ év) a 2010. évben ellátott betegek átlagéletkorához (47,36 év) képest (1. ábra).

A nők átlagéletkora átlagosan kevesebb mint 50 év volt $(49,93$ év, CI $[95 \%]=43,88-55,14)$, szemben a férfiakkal, akiknek az átlagéletkora meghaladta az 50 évet $(56,15$ év, CI [95\%] = 53,22-58,54). A vizsgálati időszak első évéhez képest a nők átlagéletkora közel 8 évvel nőtt a vizsgálati időszak utolsó évére (2010: 44,93 év, 2015: 52,92 év). A férfi betegek esetében az átlagéletkor szintén emelkedett, ugyanakkor annak mértéke kevésbé volt számottevő. mindössze 3 évvel nőtt (2010:

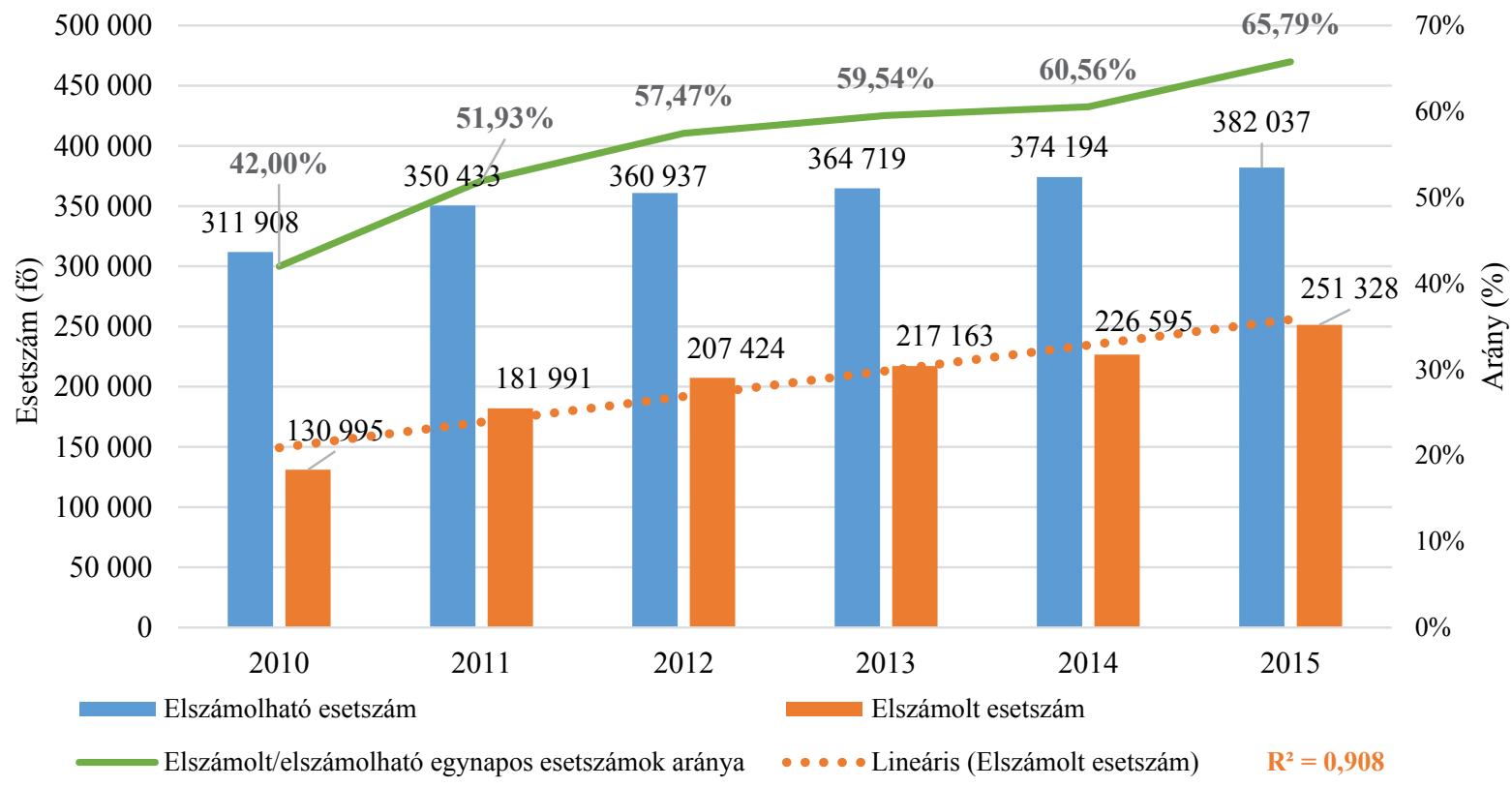

2. ábra

| Elszámolható és elszámolt egynapos sebészeti esetszámok és arányuk Magyarországon (2010-2015)

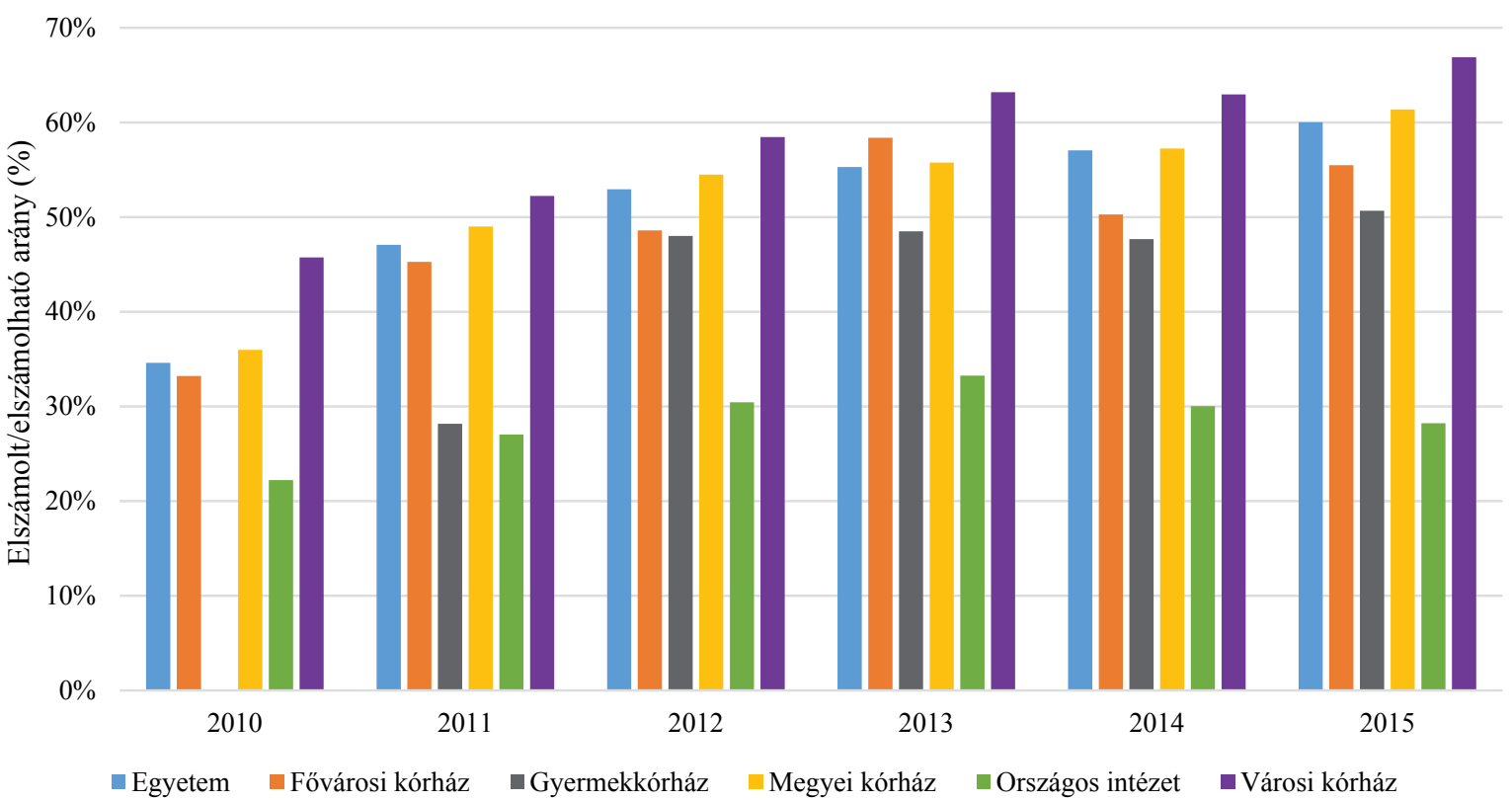

3. ábra $\quad$ Elszámolt egynapos sebészeti esetszámok aránya az elszámolható esetszámokhoz képest, intézménytípusonként (2010-2015) 


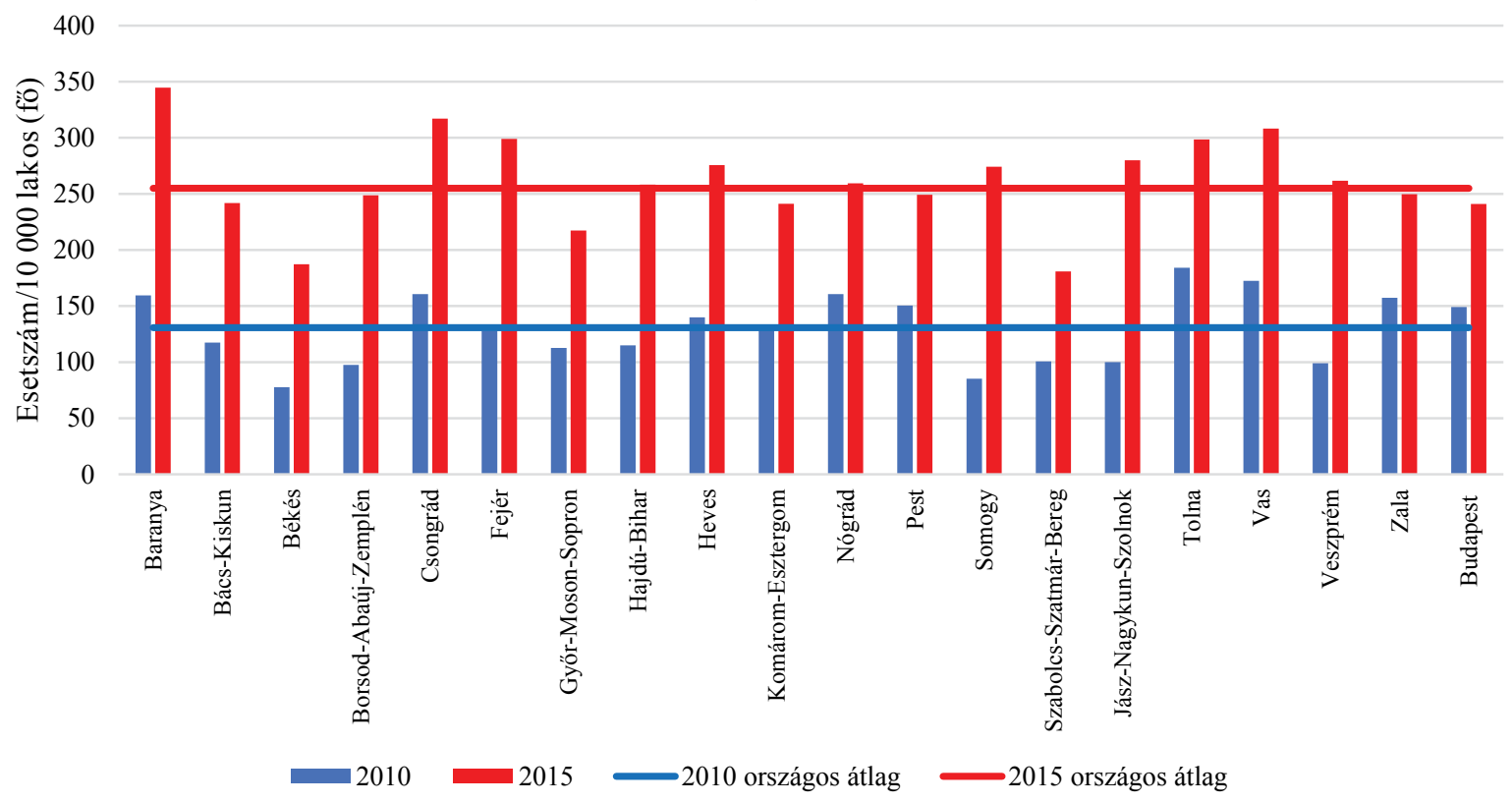

4. ábra | Tízezer lakosra vetített egynapos sebészeti esetszámok, megyénként (2010-2015)

54,74 év, 2015: 57,80 év). Az elszámolt esetszámok területén tapasztalható átlagéletkor-emelkedést magyarázhatja, hogy a vizsgálati időszakban a KSH szerinti nómenklatúra alapján a 0-14 éves korcsoport 49 670, a 15-64 éves korcsoport 209832 fővel csökkent, ezzel párhuzamosan a 65 év feletti korcsoport 100749 fóvel emelkedett.

A 2010 és 2015 közötti időszakban elszámolt egynapos sebészeti esetszámok mindössze 1,97\%-át képezte a 0-14 éves korcsoport, a következők esetén ugyanakkor már számottevő mértékben alakult az egynapos sebészeti esetszámok aránya: a 15-64 éves korcsoport képezte az esetszámok 65,59\%-át, a 65 év felettiek aránya pedig az esetszámok 32,44\%-át. A vizsgálati időszakban a 0-14 éves korcsoport 14,53\%-ban képviseltette magát a popu-

2. táblázat |A legtöbb egynapos sebészeti esetszámot elszámoló 10 szakma Magyarországon (2010-2015)

\begin{tabular}{lc}
\hline A szakma megnevezése & Összes esetszám \\
\hline Szülészet-nőgyógyászat & 410933 \\
Szemészet & 349143 \\
Sebészet & 95331 \\
Urológia & 78880 \\
Kardiológia & 60847 \\
Traumatológia & 49901 \\
Sebészeti típusú mátrix egység & 49748 \\
Ortopédia & 48436 \\
Fül-orr-gégegyógyászat & 19158 \\
Érsebészet & 12828 \\
Egyéb & 40290 \\
\hline Összesen & 1215496 \\
\hline
\end{tabular}

lációban, a 15-64 éves korcsoport 68,33\%-ban, míg a 65 év felettiek aránya $17,14 \%$ volt. Az egynapos sebészeti esetszámok évenkénti összegét összehasonlítottuk a populáció létszámának változásával, amelynek során megállapítottuk, hogy a 2010. évben a populáció 1,31\%-át alkották az egynapos sebészeti esetszámok, míg a 2015. évben kismértékú emelkedést azonosítottunk, akkor az alapsokaság 1,33\%-át képezték az egynapos esetek. Ezt az arányemelkedést magyarázhatja, hogy a népesség száma 1,59\%-kal csökkent, míg az egynapos sebészeti esetszámok 191,86\%-kal emelkedtek.

\section{Az egynapos sebészeti esetszámok aránya országosan és intézettípusonként}

Meghatároztuk a 9/1993. (IV. 2.) NM rendelet 9. számú melléklete szerint elszámolható és elszámolt egynapos sebészeti esetszámok arányát. Eredményeink szerint a vizsgálati időszak első évében az elszámolható egynapos sebészeti esetszámok 42\%-át számolták el a szolgáltatók egynapos sebészeti ellátásban. A 2011. évben ez az arány meghaladta az 51\%-ot, 2014-től pedig a $60 \%$-ot is $(60,56 \%)$. 2015-ben az elszámolható egynapos sebészeti esetszámok több mint 65\%-át számolták el a szolgáltatók egynapos sebészeti betegellátásban teljesített esetszámként $(65,79 \%)$ (2. ábra).

Az egynapos sebészeti ellátásokat teljesítő intézettípusokat vizsgálva megállapíthatjuk, hogy közel valamennyi intézettípus esetén jelentős mértékben nőtt az elszámolt egynapos sebészeti ellátások aránya (3. ábra). A 2010. évben valamennyi intézettípus esetében az egynapos sebészeti ellátásként elszámolható esetek kevesebb mint 50\%-a került elszámolásra egynapos sebészeti keretek között; a 2015. évre ez az arány az országos intézetek 
kivételével minden esetben meghaladta az 50\%-ot. A gyermekkórházak esetében a 2010. évben nem került elszámolásra egynapos sebészeti esetszám, ugyanakkor 2015-ben az elszámolható esetszámok közel 51\%-át elszámolták (50,66\%). Az egyetemek esetében jelentős mértékű emelkedést tapasztaltunk az elszámolható és az elszámolt esetszámok arányát vizsgálva. 2010-ben 35\%os arányt követően, folyamatos emelkedés mellett 2015ben több mint 60\%-át elszámolták az egyetemek az elszámolható egynapos esetszámoknak (60,03\%). A megyei kórházak esetén az egyes években meghatározott arány nagyságrendileg megegyezett az egyetemekével: 2010 -ben 35,97\%, 2015-ben 61,38\%. A vizsgálati időszak egészét tekintve a városi kórházak számolták el a legnagyobb mértékben az elszámolható egynapos esetszámokat. A 2010. évben több mint 45\%, 2015-ben közel $67 \%$.

\section{Esetszámok az ellátottak megye szerinti lakbelye alapján}

Megyei bontásban is elemeztük az egynapos sebészeti esetszámokat. Ennek megfelelő indikátora lehet a tízezer lakosra vetített egynapos esetszámok meghatározása, ugyanis a mutató figyelembe veszi az évenként változó megyei népességszámot is. A vizsgálati időszak során az ország népességszáma 158753 fóvel csökkent, s ez Borsod-Abaúj-Zemplén, illetve Baranya megye tekintetében meghaladta a 20000 föt. Mindössze két megyében és a fóvárosban volt tapasztalható e tekintetben emelkedés, az utóbbi esetén jelentős, több mint 36000 föt meghaladó mértékű, míg Győr-Moson-Sopron, illetve Szabolcs-Szatmár-Bereg megyében mérsékeltebb ütemú népességszaporulat volt azonosítható.

A 2010. évben országosan 130,81 esetszámot határoztunk meg tízezer lakosonként. Ez a mutató 2015ben számottevő mértékben nőtt $(255,04$ esetszám/10 000 lakos). A tízezer lakosra vetített országos értéket 2010-ben Baranya (159,44), Csongrád (160,69), Heves $(139,99)$, Komárom-Esztergom (132,86), Nógrád $(160,60)$, Pest $(150,54)$, Tolna $(184,16)$, Vas $(172,46)$ és Zala $(157,42)$ megyében, valamint Budapesten $(149,14)$ haladta meg az egynapos sebészeti esetszám.

2015-ben Baranya $(344,64)$, Csongrád $(317,11), \mathrm{Fe}-$ jér (299,03), Hajdú-Bihar (258,21), Heves $(275,71)$, Nógrád $(259,39)$, Somogy $(274,22)$, Jász-NagykunSzolnok $(279,89)$, Tolna $(298,54)$, Vas $(308,11)$ és Veszprém $(261,76)$ megye esetében haladta meg a megyei, tízezer lakosra vetített egynapos sebészeti esetszám az országos értéket.

A tízezer lakosra vetített egynapos sebészeti esetszámok megyénként meghatározott értékét a 4 . ábra ismerteti.
3. táblázat A 20, leggyakrabban elvégzett egynapos sebészeti beavatkozás Magyarországon (2010-2015)

\begin{tabular}{|c|c|c|c|}
\hline $\begin{array}{l}\text { Beavatkozási } \\
\text { kódok }\end{array}$ & A beavatkozás megnevezése & Összesen & Arány \\
\hline 51474 & $\begin{array}{l}\text { Szürkehályog-mútét phaco- } \\
\text { emulsificatiós módszerrel, } \\
\text { hajlítottmúlencse-beültetés }\end{array}$ & 308556 & $25,39 \%$ \\
\hline 57510 & Interruptio vacuummal & 133315 & $10,97 \%$ \\
\hline 56906 & Frakcionált curettage & 118577 & $9,76 \%$ \\
\hline 39430 & ESWL - vesekő & 45930 & $3,78 \%$ \\
\hline 56899 & Curettage uteri & 39546 & $3,25 \%$ \\
\hline 56905 & $\begin{array}{l}\text { Curettage inkomplett abortusz } \\
\text { után }\end{array}$ & 38599 & $3,18 \%$ \\
\hline 58040 & $\begin{array}{l}\text { Meniscectomia, partialis, } \\
\text { artroszkópos }\end{array}$ & 24788 & $2,04 \%$ \\
\hline 57521 & Interruptio laminariatágítással & 23787 & $1,96 \%$ \\
\hline 12660 & Szívkatéterezés, alapvizsgálat & 20929 & $1,72 \%$ \\
\hline 57530 & Amniocentesis & 20894 & $1,72 \%$ \\
\hline 12220 & $\begin{array}{l}\text { Ranibizumab intravitrealis } \\
\text { injektálása }\end{array}$ & 20473 & $1,68 \%$ \\
\hline 57883 & $\begin{array}{l}\text { Belső fémrögzítés eltávolítása } \\
\text { (szeg, lemez stb., kivéve: } \\
\text { tűződrót) }\end{array}$ & 18759 & $1,54 \%$ \\
\hline 39432 & ESWL - uréterkő & 18248 & $1,50 \%$ \\
\hline 53846 & $\begin{array}{l}\text { Crossectomia + stripping + } \\
\text { tágult vénák eltávolítása }\end{array}$ & 15823 & $1,30 \%$ \\
\hline 12750 & $\begin{array}{l}\text { Szívkatéterezés, egyéb artériás } \\
\text { percutan behatolással }\end{array}$ & 15814 & $1,30 \%$ \\
\hline 56723 & Méhpolip eltávolítása & 15004 & $1,23 \%$ \\
\hline 52740 & Szájüreg plasztikai helyreállítása & 14583 & $1,20 \%$ \\
\hline 55310 & $\begin{array}{l}\text { Hernioplastica inguinofemora- } \\
\text { lis c. implant. }\end{array}$ & 13516 & $1,11 \%$ \\
\hline 86051 & Thermotherapia prostatae & 12773 & $1,05 \%$ \\
\hline 51492 & Capsulotomia lentis & 11455 & $0,94 \%$ \\
\hline Egyéb & & 284127 & $23,38 \%$ \\
\hline Összesen & & 1215496 & $100,00 \%$ \\
\hline
\end{tabular}

ESWL $=$ a vese és a vesevezeték köveinek kezelése testen kívül gerjesztett lökéshullámmal

\section{Egynapos sebészeti esetszámok az ellátószakmák és az elvégzett beavatkozások szerint}

A szülészet-nőgyógyászati szakma teljesítette a legtöbb egynapos sebészeti esetszámot, amely az összes esetszám közel 34\%-át képezte (410 933 eset). Számottevő ezenkívül a szemészeti szakma egynapos sebészeti teljesítménye, amely az összes egynapos esetszám több mint egynegyed részét jelentette (319 143 eset). A szülészetnőgyógyászati és a szemészeti szakma hazai egynapos sebészeti ellátásban tapasztalható fokozott jelentőségét alátámasztja, hogy az e két szakma által teljesített esetszám az összes egynapos sebészeti esetszám több mint 62\%-a (760 077 esetszám). Az esetszámok alapján ki- 
emelendő szakmák közé sorolandó még a sebészet, az urológia, a kardiológia, a traumatológia, az ortopédia, a fül-orr-gégegyógyászat, valamint az érsebészet. Az itt felsorolt szakmák által teljesített esetszámok az összes egynapos esetszám közel 97\%-át alkotják (1 175206 esetszám). Az egyes szakmák esetében meghatározott részletes adatokat a 2. táblázat ismerteti.

A vizsgálat során elkészítettük a 20, legnagyobb mértékben elvégzett egynapos sebészeti beavatkozás listáját, amelynek részletes adatait a 3. táblázat ismerteti. A táblázatban feltüntetett 20, leggyakrabban elvégzett beavatkozás az összes egynapos sebészeti beavatkozás több mint 76\%-át képezte $(76,62 \%)$. A beavatkozások közül kiemelendő az 51474-es OENO-kóddal rögzített szürkehályog-mútét, amely a vizsgálati időszak során a legnagyobb mértékben került elvégzésre (308 556 beavatkozás), és az összes egynapos sebészeti beavatkozás több mint egynegyed részét képezte. A szemészeti szakmához tartozó további beavatkozások: a 12220-as OENO-kóddal rögzített intravénás ranibizumabinjektálás (20 473 beavatkozás), valamint az 51492-es OENO-kód alatt rögzített capsulotomia lentis beavatkozás (11 455 beavatkozás). A legnagyobb mértékben elvégzett 20 beavatkozás között többségében a szülészet-nőgyógyászati szakmához tartozó beavatkozások találhatók: interruptio vacuummal (OENO 57510), frakcionált curettage (OENO 56906), curattage uteri (OENO 56899), curettage inkomplett abortusz után (OENO 56906), interruptio laminariatágítással (OENO 57521), amniocentesis (OENO 57530), valamint a méhpolip eltávolítása (OENO 56723). Ezeken kívül a leggyakrabban elvégzett 20 beavatkozás között megtalálhatók még az urológiához, a kardiológiához, az ortopédia-traumatológiához, valamint a fül-orr-gégegyógyászathoz kapcsolódó eljárások is.

\section{Megbeszélés}

Az egynapos sebészeti ellátás tekintetében kijelenthető, hogy az ellátási típus közfinanszírozott formában elszámolt esetszámai hazánkban jelentős mértékben emelkedtek az elmúlt években, a nemzetközi gyakorlathoz hasonlóan [33-36]. A megállapítást igazolja a munkacsoportunk által mind az országos vetületben ismertetett eredményeknek, mind pedig a megyei vagy intézettípusonkénti szempontból meghatározott esetszámoknak az alakulása is. Az egynapos sebészeti esetszámok növekedési dinamikáját elemezve azok a vizsgálati időszak első évétől lineárisan emelkedtek, ugyanakkor az esetszámok növekedése az egyes évek tekintetében eltérő ütemben zajlott. Már a 2010. évet megelőző időszakban is azonosították a hazai egynapos sebészeti betegellátásban az emelkedő esetszámok jelenségét mind megyei, mind pedig országos szinten [3]. A városi kórházak voltak azok az intézettípusok, amelyek a vizsgálati idősáv során az egynapos sebészeti ellátásban a legkedvezőbb mértékben optimalizálták teljesítményüket. Ezzel megegyező ered- ményeket egy korábbi időszakról már más kutatás is megfogalmazott [37].

Az ezredfordulót követően már azonosították a szülészet-nőgyógyászati szakma egynapos sebészeti ellátásban jelentkező eredményeit [38]. Vizsgálatunk során megállapítottuk, hogy az elszámolt egynapos sebészeti esetek több mint 30\%-a a szülészeti-nőgyógyászati szakma által került ellátásra. Beavatkozásszinten pedig kiemelendő a szürke hályog megszüntetését célzó beavatkozások jelentős mennyisége, amit egy korábbi kutatásban is megállapítottak már [39].

Az egynapos sebészeti ellátások területén kevés nemzetközi összehasonlító adat áll rendelkezésre. Jellemzően az észak-európai országok járnak élen az egynapos sebészeti ellátásban. Franciaországban 2010 és 2014 között az egynapos sebészeti beavatkozások aránya nem haladta meg az 50\%-ot, a magyarországi eredmények ezek alapján kedvezőbbnek bizonyultak [40].

A nemzetközi tapasztalatok ugyanakkor döntően azt mutatják, hogy Magyarország számos területen némi lemaradásban van. Az OECD (Organisation for Economic Co-operation and Development, Gazdasági Együttmüködési és Fejlesztési Szervezet) elemzése szerint 2015ben az országok a cataractamütéteknek átlagosan a 87\%át végezték egynapos formában, míg Magyarországon az 54\%-át [41, 42]. Hazánkban a cataractamútétek egynapos sebészetben történő ellátásának aránya a 2015. évi adatok alapján jelentős mértékben elmarad az OECDátlagtól, ugyanakkor az ezt megelőző évekhez képest jelentős mértékű javulás azonosítható (2013: 37\%, 2011: 30\%, 2009: 24\%, 2007: 12\%) [43-45].

A hazai egynapos sebészeti ellátásoknak a 2010 előtti időszakban tapasztalt marginális szerepét jellemzi, hogy 2008-ban az egynapos sebészettel összefüggő egészségbiztosítói kiadás aránya az összes gyógyításhoz kapcsolódó kiadás mindössze $2 \%$-át jelentette, amely az akkori uniós átlag 50\%-a volt [46].

Európa számos országában jellemző, hogy a cataractamütétek ellátása az egynapos sebészeti ellátás felé tolódik, az egyes országokban ugyanakkor eltérő ennek ütemezése. A 2004 és 2014 közötti időszakban a cataractamütétek egynapos sebészeti formában történő ellátása Észtországban, Lengyelországban és Portugáliában fejlődött intenzíven. Szlovákiában és Ausztriában a Magyarországon tapasztaltakhoz képest szintén jellemző, hogy az egynapos sebészeti ellátás kevésbé terjedt el. Ennek hátterében legfóképpen a földrajzi és demográfiai mutatók sajátosságai, részben pedig az egynapos sebészeti ellátások kedvezôtlen finanszírozási technikái húzódnak meg [47, 48].

Napjainkban az egynapos sebészeti betegellátás kifejezett jelentősége vitathatatlan - a kedvező szakmapolitikai és finanszírozói eljárások ismeretében -, ennek alapján az ellátási típus jelentőségének fokozódását és így az ellátott egynapos sebészeti esetszámok további növekedését prognosztizálhatjuk Magyarországon is. 
Anyagi támogatás: A közlemény az „EFOP-2.2.0-162016-00004 Aktín fekvőbeteg-ellátási forma kiváltása az egynapos sebészeti ellátás rendszerének fejlesztésével" pályázat támogatásával készültt.

Szerzői munkamegosztás: P. R., M. B., E. D., G. L., G. E. M., B. I.: A hipotézis kidolgozása, a kézirat megszövegezése. P. R., K. D., N. N., S. B.: Szakirodalom-kutatás. P. R., E. D., B. I., R. L. B.: Adatelemzés, statisztika. A cikk végleges változatát valamennyi szerző elolvasta és jóváhagyta.

\section{Érdekeltségek: A szerzóknek nincsenek érdekeltségeik.}

\section{Irodalom}

[1] Jarrett PE, Staniszewski A. The development of ambulatory surgery and future challenges. In: Lemos P, Jarrett P, Philip B. (eds.) Day surgery. Development and practice. International Association for Ambulatory Surgery, Brussels, 2006; pp. 21-34. Available from: http://www.iaas-med.com/files/historical/ DaySurgery.pdf [accessed: July 16, 2018].

[2] Lafortune G, Balestat G, Durand A, et al. Comparing activities and performance of the hospital sector in Europe: how many surgical procedures performed as inpatient and day cases? OECD Health Division, Paris, 2012. Available from: https://www. oecd.org/health/Comparing-activities-and-performance-ofthe-hospital-sector-in-Europe_Inpatient-and-day-cases-surgicalprocedures.pdf [accessed: July 16, 2018].

[3] Pásztélyi Zs. Report on the use of funds spent on one-day surgical care. [Jelentés az egynapos sebészeti ellátásra fordított pénzeszközök hasznosulásáról.] IME Interdiszciplináris Magyar Egészségügy 2010; 9: 5-9. [Hungarian]

[4] Ballardini B, Cavalli M, Manfredi GF, et al. Surgical treatment of breast lesions at a day centre: experience of the European Institute of Oncology. Breast 2016; 27: 169-174.

[5] De Kok M, van der Weijden T, Kessels AG, et al. Patients' opinions on quality of care before and after implementation of a short stay programme following breast cancer surgery. Breast 2010; 19: 404-409.

[6] Szendrői M, Kiss J, Perlaky T, et al. Change of paradigm in the surgical treatment of metastatic diseases of bone. Part I. Bony metastases of the extremities and pelvis. [Paradigmaváltás a csontmetasztázisok sebészetében. I. Végtagi és medencelokalizációjú áttétek.] Orv Hetil. 2017; 158: 1563-1569. [Hungarian]

[7] Papp G, Bánky B, Lakatos M, et al. New perspectives in rectal cancer surgery: Transanal total mesorectal excision. Initial experiences. [Új távlatok a végbélrák sebészetében: Transanalis teljes mesorectum excisio. Kezdeti eredményeink.] Orv Hetil. 2018; 159: 16-22. [Hungarian]

[8] Bowonratwet P, Ondeck TN, Nelson SJ, et al. Comparison of outpatient vs inpatient total knee arthroplasty: an ACS-NSQIP analysis. J Arthroplasty 2017; 32: 1773-1778.

[9] Lombardi AV Jr, Barrington JW, Berend KR, et al. Outpatient arthroplasty is here now. Instr Course Lect. 2016; 65: 531-546.

[10] Mitchell BJ, Harrow B. Costs and outcomes of inpatient versus outpatient hernia repair. Health Policy 1994; 28: 143-152.

[11] O'Neill JP, Young O, Conlon B. Major otology day case surgery: viable, cost efficient and safe. Ir J Med Sci. 2011; 180: 841-844.

[12] Oh J, Perlas A, Lau J, et al. Functional outcome and cost-effectiveness of outpatient vs inpatient care for complex hind-foot and ankle surgery. A retrospective cohort study. J Clin Anaesth. 2016; 35: 20-25.

[13] Hessman C, Fields J, Schuman E. Outpatient thyriodectomy: is it a safe and reasonable option? Am J Surg. 2011; 201: 565-569.
[14] Duff M, Mofidi R, Nixon SJ. Routine laparascopic repair of pri mary unilateral inguinal hernias - a viable alternative in the day surgery unit? Surgeon 2007; 5: 209-212.

[15] Billin SP, Crouthamel MR, Oling S, et al. Outpatient laparoscopic sleeve gastrectomy in a free-standing ambulatory surgery center: first 250 cases. Surg Obes Relat Dis. 2014; 10: 101-105.

[16] O'Neill T, Itte V, Bourke G. MRSA screening in ambulatory upper limb trauma day cases. Br J Health Care Manag. 2014; 20: $435-439$.

[17] Morillo-García Á, Aldana-Espinal JM, Olry de Labry-Lima A, et al. Hospital costs associated with nosocomial infections in a pediatric intensive care unit. Gac Sanit. 2015; 29: 282-287.

[18] Hundt AS, Carayon P, Springman S, et al. Outpatient surgery and patient safety - The patient's voice. In: Henriksen K, Battles JB, Marks ES, et al. (eds.) Advances in patient safety: from research to implementation. Vol. 4, Programs, tools, and products. AHRQ Publication No. 05-0021-4. Agency for Healthcare Research and Quality, Rockville, MD, 2005; pp. 445-459.

[19] Rebibo L, Dhahri A, Badaoui R, et al. Laparoscopic sleeve gastrectomy as day-case surgery (without overnight hospitalization). Surg Obes Relat Dis. 2015; 11: 335-342.

[20] Decree 16/2002 (XII. 12.) of Ministry of Health, Social and Family Affairs on the professional conditions of one-day surgical and cure-related benefits. [16/2002. (XII. 12.) EszCsM rendelet az egynapos sebészeti és a kúraszerúen végezhető ellátások szakmai feltételeirôl.] [Hungarian]

[21] Decree 9/1993 (IV. 2.) of Ministry for National Economy on certain aspects of social security financing of healthcare. $[9 / 1993$. (IV. 2.) NM rendelet az egészségügyi szakellátás társadalombiztosítási finanszírozásának egyes kérdéseirôl.] [Hungarian]

[22] Hungarian Central Statistical Office. Population by gender in 2001-2018. [Központi Statisztikai Hivatal (KSH). STADAT, A lakónépesség nem szerint 2001-2018.] Available from: http://www.ksh.hu/stadat_eves_6_1 [accessed: July 17, 2018]. [Hungarian]

[23] Endrei D, Molics B, Ágoston I. Multicriteria decision analysis in the reimbursement of new medical technologies: real-world experiences from Hungary. Value Health 2014; 17: 487-489.

[24] Boncz I, Vajda R, Ágoston I, et al. Changes in the health status of the population of Central and Eastern European countries between 1990 and 2010. Eur J Health Econ. 2014; 15(Suppl 1): S137-S141.

[25] Boncz I, Nagy J, Sebestyén A, et al. Financing of health care services in Hungary. Eur J Health Econ. 2004; 5: 252-258.

[26] Boncz I, Evetovits T, Dózsa Cs, et al. The Hungarian care managing organization pilot program. Value Health Reg Issues 2015; 7: 27-33.

[27] Greenberg D, Mohamed Ibrahim MIB, Boncz I. What are the challenges in conducting cost-of-illness studies? Value Health Reg Issues 2014; 4: 115-116.

[28] Endrei D, Zemplényi A, Molics B, et al. The effect of performance-volume limit on the DRG based acute care hospital financing in Hungary. Health Policy 2014; 115: 152-156.

[29] Boncz I, Kaló Z, Mohamed Ibrahim MIB, et al. Further steps in the development of pharmacoeconomics, outcomes research, and health technology assessment in Central and Eastern Europe, Western Asia, and Africa. Value Health Reg Issues 2013; 2: 169170.

[30] Gulácsi L, Brodszky V, Péntek M, et al. History of health technology assessment in Hungary. Int J Technol Assess Health Care 2009; 25(Suppl 1): 120-126.

[31] Boncz I, Sebestyén A. Financial deficits in the health services of the UK and Hungary. Lancet 2006; 368: 917-918.

[32] Boncz I, Dózsa C, Kaló Z, et al. Development of health economics in Hungary between 1990-2006. Eur J Health Econ. 2006; 7(Suppl 1): S4-S6.

[33] Anderson T, Walls M, Canelo R. Day case surgery guidelines. Surgery 2017; 35: 85-91. 
[34] Mouton A, Le Strat V, Medeivielle D, et al. Patient's satisfaction after outpatient forefoot surgery: study of 619 cases. Orthop Traumatol. Surg Res. 2015; 101: 217-220.

[35] Olaguon JG, Popoola SO, Oluwadiya KS, et al. The feasibility and acceptability of day case surgery in secondary health facility in Nigeria. Egypt J Anaesth. 2016; 32: 555-558.

[36] Pónusz R, Németh N, Kovács D, et al. Analysis the number of cases of one-day surgical patient care in Hungarian University Clinical Centre's between 2010-2015. Value Health 2018; 21(Suppl 1): S114-S115.

[37] Mészáros J. One-day surgery in Hungary 2010-2012. [Egynapos sebészet helyzete Magyarországon 2010-2012.] IME Interdiszciplináris Magyar Egészségügy 2013; 12: 5-7. [Hungarian]

[38] Boncz I. Application of overnight interventions in the obstetrics and gynecology area from the point of view of the financier side. [Egynapos beavatkozások alkalmazása a szülészeti-nőgyógyászati területen a finanszírozói oldal szemszögéből.] Magy Nóorv L. 2002; 65: 453-458. [Hungarian]

[39] Pónusz R, Németh N, Kovács $\mathrm{D}$, et al. The impact of ophthalmology in the Hungarian one-day surgery. Value Health 2018; 21(Suppl 1): S114.

[40] Hulet C, Rochcongar A, Court C. Developments in ambulatory surgery in orthopedics in France in 2016. Orthop Traumatol Surg Res. 2017; 103(1 Suppl): S83-S90.

[41] OECD. Health at a Glance 2017: OECD Indicators. OECD Publishing, Paris, 2017. https://doi.org/10.1787/19991312
[42] OECD. Health at a Glance 2015: OECD Indicators. OECD Publishing, Paris, 2015. http://dx.doi.org/10.1787/health_ glance-2015-en

[43] OECD. Health at a Glance 2013: OECD Indicators. OECD Publishing, Paris, 2013. http://dx.doi.org/10.1787/health_ glance-2013-en

[44] OECD. Health at a Glance 2011: OECD Indicators. OECD Publishing, Paris, 2011. http://dx.doi.org/10.1787/health_ glance-2011-en

[45] OECD. Health at a Glance 2009: OECD Indicators. OECD Publishing, Paris, 2009. DOI 10.1787/health_glance-2009-en

[46] OECD. Health at a Glance 2010: OECD Indicators. OECD Publishing, Paris, 2010. http://dx.doi.org/10.1787/health_ glance-2010-en

[47] Gianno MM, Lenzi J, Bonaudo M, et al. The switch between cataract surgical settings: evidence from a time series analysis across 20 EU countries. PloS ONE 2018; 13: e0192620.

[48] Gavurova B, Soltes M. System of day surgery in Slovakia: analysis of pediatric day surgery discrepancies in the regions and their importance in strategy of its development. Ekonimika a Management 2016; 19: 74-91.

(Pónusz Róbert, Pécs, Mária utca 7. , 7621 e-mail: robert.ponusz@etk.pte.hu)

\section{A rendezvények és kongresszusok híranyagának leadása}

a lap megjelenése előtt legalább 40 nappal lehetséges, a 6 hetes nyomdai átfutás miatt. Kérjük megrendelőink szíves megértését.

A híranyagokat a következő címre kérjük: Orvosi Hetilap titkársága: edit.budai@akademiai.hu Akadémiai Kiadó Zrt.

A cikk a Creative Commons Attribution 4.0 International License (https://creativecommons.org/licenses/by/4.0/) feltételei szerint publikált Open Access közlemény, melynek szellemében a cikk bármilyen médiumban szabadon felhasználható, megosztható és újraközölhető, feltéve, hogy az eredeti szerző és a közlés helye, illetve a CC License linkje és az esetlegesen végrehajtott módosítások feltüntetésre kerülnek. (SID_1) 